\title{
Systemic Sclerosis Associated With Hashimotos Thyroiditis - A Rare Case Report
}

\author{
Dr. Rashmi A B ${ }^{1}$, Dr. B K Vishwanath ${ }^{2}$
}

\section{Introduction}

Systemic Sclerosis (Ssc) is a chronic multisystem disease of unknown etiology characterized by skin induration, thickening, accompanied by fibrosis and chronic inflammatory infiltration of internal organs, microvascular damage and immune dysfunction.

Several epidemiological studies have revealed the cooccurrence of other autoimmune diseases (AIDs) within patients with Ssc. The most prevalent associated AIDs were autoimmune thyroid disease $(10.4 \%)$ followed by Sjogren's syndrome $(7.7 \%)$ and dermatopolymyositis/ polymyositis $(5.6 \%)$. (1)

\section{Case Report}

A 45 year old female patient presented with complaints of tightness of skin over face and extremities since 8 months, difficulty in opening mouth since 7 months. There was history of easy fatiguability and joint pain affecting her daily routine with history of numbness and pain in the upper limbs which aggrevated on exposure to cold and stress. On examination, skin over face, upper limbs and lower limbs were tight, indurated and shiny. Multiple digital pitted scars were present. Pinched appearance of nose, microstomia, salt pepper appearance were noted.ANA antibodies were positive.Skin biopsy was done and was suggestive of systemic sclerosis. Investigations - haemoglobin -8.9g/dl. Liver function tests were mildly impaired, Thyroid profile was done which showed elevated TSH levels and decreased T3 and T4 levels. FNAC of thyroid swelling of left lobe was done. Cytological features were suggestive of Hashimotos thyroiditis. Antimicrosomal antibodies $(180 \mathrm{IU} / \mathrm{mL})$ and anti thyroglobulin antibodies $(1635 \mathrm{IU} / \mathrm{mL})$ were positive.

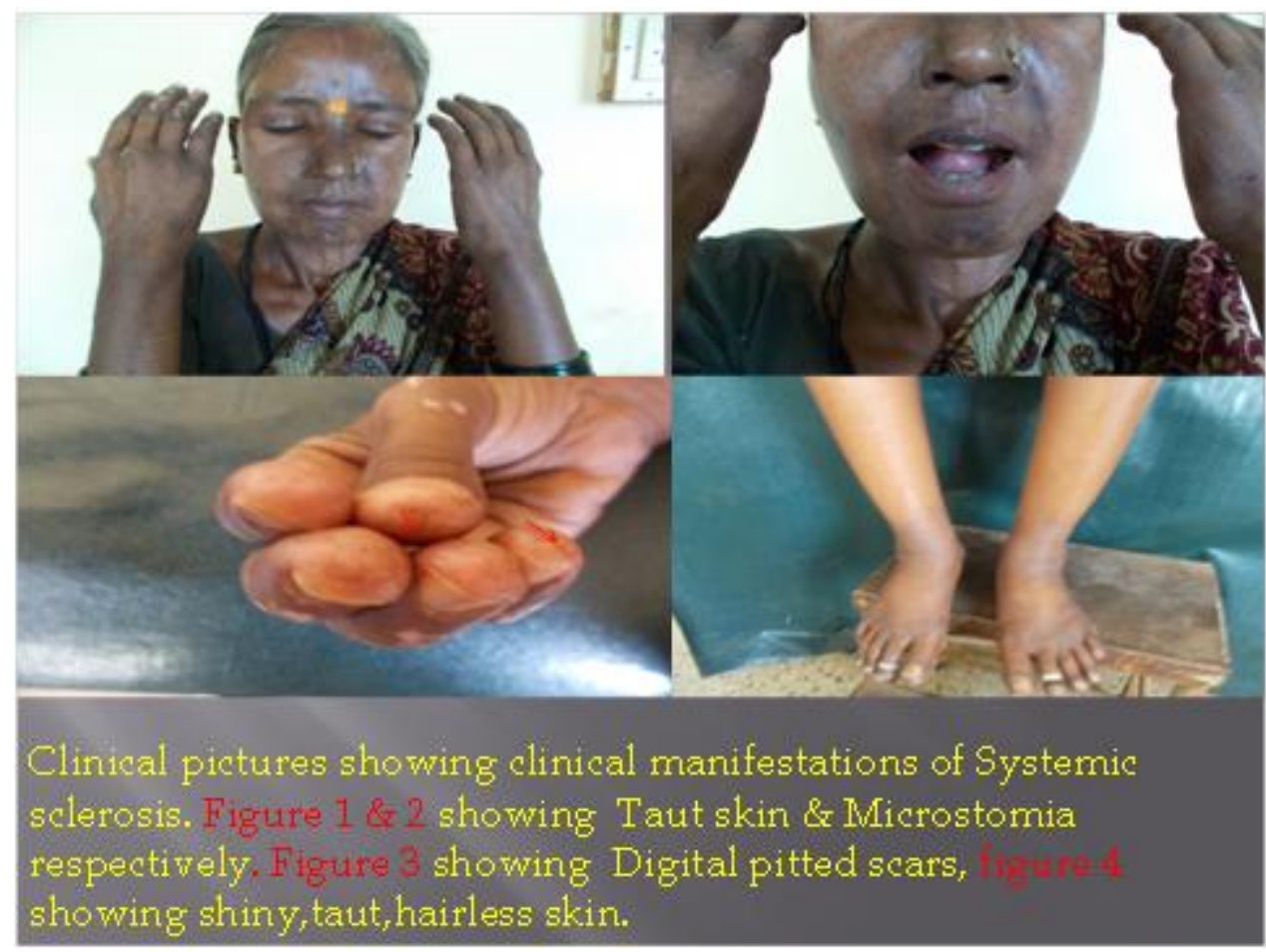


International Journal of Science and Research (IJSR)

ISSN (Online) : 2319-7064

Index Copernicus Value (2013) : 6.14 | Impact Factor (2014) : 5.611

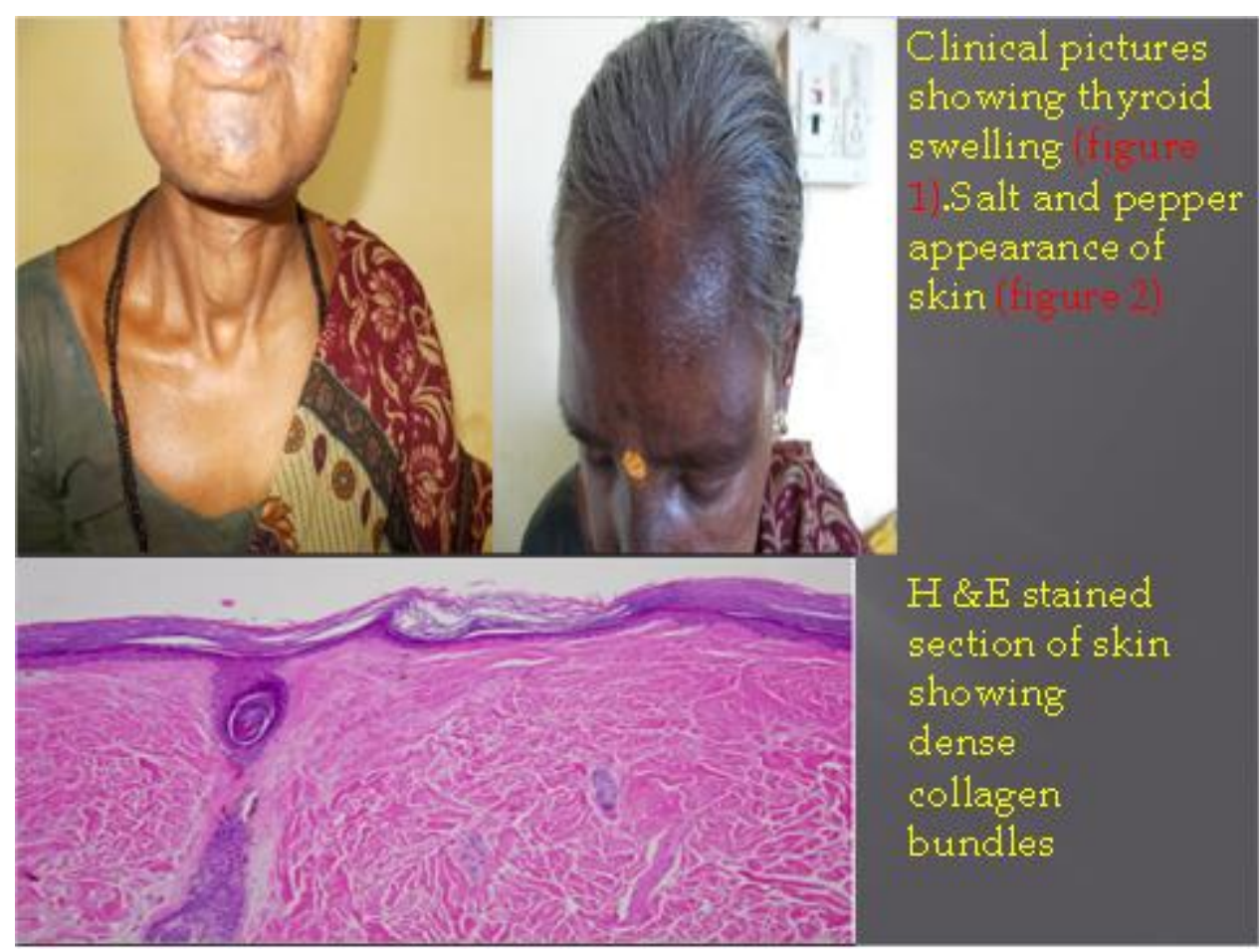

\section{Conclusion}

A knowledge of this association is of fundamental importance to the clinician that, in treating an autoimmune disease, remains alert to other ones. The Ssc subjects with anti-TPO antibodies, a higher frequency of HLA-DR 15 allele is seen than the patients without these antibodies. (2)

Thus, associations of AIDs and autoimune background in Ssc have to be considered for further therapeutic and biological investigations in Ssc. (3)

\section{References}

[1] Elhai M, Avouac J, Kahan A, Allanore Y. Systemic sclerosis at the crossroad of polyautoimmunity. Autoimmun Rev.2013;12:1052-7.

[2] Molteni M, Barili M, Eisera N, Scrofani S, Mascagni B, Zulian $\mathrm{C}$, et al. Anti-thyroid antibodies in Italian scleroderma patients: association of anti-thyroid peroxidase (anti-TPO) antibodies with HLA-DR15. Clin Exp Rheumatol. 1997;15:529-34.

[3] Avouac J, Airò P, Dieude P, Caramaschi P, Tiev K, Diot E, et al. Associated autoimmune diseases in systemic sclerosis define a subset of patients with milder disease: results from 2 large cohorts of European Caucasian patients. J Rheumatol. 2010;37:608-14.

[4] van den Hoogen F, Khanna D, Fransen J, Johnson SR, Baron M, Tyndall A, et al. 2013 classification criteria for systemic sclerosis: an American College of Rheumatology/European league against rheumatism collaborative initiative. Ann Rheum Dis. 2013;72:174755.

[5] Clements PJ, Lachenbruch P. Siebold. Inter and Intraobsever variability of total skin thickness score (modified Rodnan TSS) in systemic sclerosis. J Rheumatol. 1995;22:1281-5.
[6] Nancy AL, Yehuda S. Prediction and prevention of autoimmune disorders. Arch Dermatol Res. 2009; 301:57-64.

[7] Dayan CM, Daniels GH. Chronic autoimmune thyroiditis. N Engl J Med. 1996; 335:99-107.

[8] Allanore Y, Avouac J, Kahan A. Systemic sclerosis: an update in 2008. Joint Bone Spine. 2008; 75:650-5.

[9] $\mathrm{Hu}$ PQ, Fertig $\mathrm{N}$, Medsger Jr TA, Wright TM. Correlation of serum anti-DNA topoisomerase I antibody levels with disease severity and activity in systemic sclerosis. Arthritis Rheum. 2003; 48:1363-73.

[10] Kuwana M, Kaburaki J, Mimori T, Kawakami Y, Tojo T. Longitudinal analysis of autoantibody response to topoisomerase I in systemic sclerosis. Arthritis Rheum. 2000; 43:1074-84. 